\title{
女性での等容性排尿筋収縮圧の測定
}

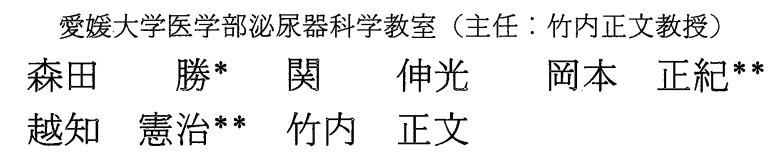

\section{ISOMETRIC DETRUSOR PRESSURE IN THE FEMALE PATIENT}

\author{
Masaru MORITA, Nobumitsu SEKI, Masaki OKAMOTO, \\ Kenji OCHI and Masafumi TAKEUCHI \\ Department of Urology (Director: Prof. M. Takeuchi), \\ Ehime University School of Medicine, Ehime, Japan
}

A total of 30 patients, comprising 7 normal female volunteers, 13 patients with enuresis, 3 patients with stress incontinence and 7 patients with neurogenic bladder dysfunction, underwent studies of isometric detrusor pressure with voluntary and forced flow-stop techniques. Different functions of detrusor contraction were estimated by measurement of maximum isometric detrusor pressure by these two techniques. Maximum isometric pressure curves with these 2 techniques also consist of 2 and 3 phases, respectively, as already reported with male patients ${ }^{5}$. The first phase of each method is a linearly increasing curve, the slope of which seems to indicate the speed of isometric detrusor contraction. The second phase in the curve obtained by the voluntary flow-stop technique is considered to be an inhibitory phase, while that obtained by the forced technique is considered to be a continuing phase followed by a plateau, the third phase.

The maximum isometric pressures obtained with the forced flow-stop technique were statistically higher than those obtained with the voluntary flow-stop technique in normal female volunteers and patients with enuresis $(\mathrm{p}<0.05)$. There was no statistical difference in the speed of detrusor contractions obtained with either technique in these patients. There also were relatively good correlations between the maximum isometric pressure and the speed of detrusor contraction obtained with two flow-stop techniques as already reported for male patients ${ }^{5}$. The forced flow-stop technique was necessary to measure the maximum isometric pressure in patients with neurogenic bladder dysfunction, many of whom could not stop urinary flow voluntarily.

\footnotetext{
要旨: 正常女性 7 例, 遺尿症13例, 腹圧性尿失禁症 3 例, 神経因性膀胱患者 7 例の計 30 例で意識的及び 強制的尿流中断による等容性排尿筋収縮の測定を行った。これらの 2 種類の尿流中断による等容性排尿 筋収縮の測定はそれぞれ排尿笳収縮の異なった機能を評価するものである。これらの 2 つ方法での等 容性排尿笳収縮曲線は男性に预けると同様に 2 つ 3 つの相に分けることができた。これらの内の第 1 の相はほぼ直線的であり，これは排尿筋収縮スピードを示すものだと考兄られた。意識的尿流中断によ り得られる曲線での第 2 相は抑制相と考兄られる. 強制的尿流中断での第 2 相は排尿筋収縮の持続相と 考号れ，これは第 3 相の平担相へと典型的には移っていく。

2 つ尿流中断方法での等容性排尿笳収縮圧は正常女性，遺尿症の各群で有意に強制的方法による方

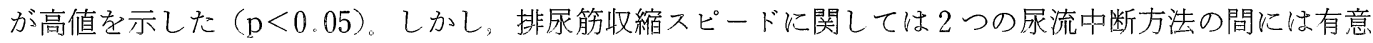
差はみられなかった，等容性排尿笳収縮圧と排尿筋収縮スピードには男性の場合と同様に 2 つ尿流中 断方法でそれぞれ比較的いい相関関係がみられた。神経因性膀胱患者では意識的尿流中断ができる症例 は少なく，等容性排尿筋収縮の測定には強制的尿流中断が必要であった。
}

*こうない坂医院

**衣山クリニック 


\section{緒言}

臨床上，蓄尿及び排尿の異常を検査する場合，種々 の尿水力学検査が行われている. そして, 膀胼排尿筋 に関する検査としては膀胱内王測定, 排尿時多チャン ネル測定が一般的であり，これらの検查により得られ た排尿笳に関するパラメーターとして蓄尿時のものは コンプライアンスが，排尿時のものは排尿時最大排尿 筋収縮圧（ $\mathrm{P}_{\text {det }}, \max$ と略す）が I.C.S. ${ }^{1}$ Kよって定義 されて使用されている，排尿時の排尿筋収縮を検討す る場合, $\mathrm{P}_{\text {det }}, \max$ は重要なパラメーターと考学られ るが，同一人に和いて尿道抵抗により変化すると思わ れる為, これのみで下部尿路の閉塞状態, 又は排尿筋 収縮の強さをあらわすことには無理があると考えられ る。尿流を中断させた際の排尿筋収縮を測定すること は $\mathrm{P}_{\text {det }}, \max よ り$ 排尿筋収縮の質を更に詳しく検査す るものであり, $\mathrm{P}_{\text {det }}, \max$ の欠点を補える可能性があ

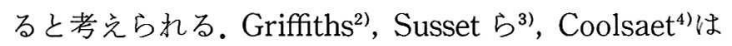
排尿中に尿流を中断させることによって, この時の等 容性最大排尿筋収縮圧及び収縮率を測定し，排尿筋収 縮の強さの検討を行っている. 我々は以前, 尿道外括 約筋による意識的方法と手指又は装具による強制的方 法の 2 種類の尿流中断の方法を用いて, 男性での排尿 筋収縮を検討して報告した5). そこで, 今回, 我々は女 性患者に㧍いて意識的及び強制的尿流中断により等容 性排尿筋収縮圧及び収縮スピードを測定して検討を 行ったので報告する。

\section{対象と方法}

下部尿路に異常のみられない正常女性 7 例, 遺㽷症 13例, 腹圧性尿失禁症 3 例, 神経因性膀脱患者 7 例の 計30例で検討を行った。年龄は正常女性は30歳から61

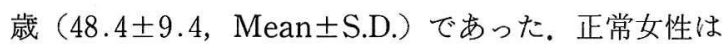
当院に入院した上部尿路疾患の患者で, 検査の承諾を 得て行われた。正常排尿かどらかは尿流測定，及び今 回の検査の際の膀脱内圧測定によって判定を行った。

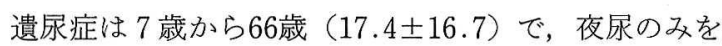
示したものは 3 例, 昼間遺尿のみを示したものは 3 例 で残りの 7 例は昼間及び夜間遺尿を示した。そして， 昼間遺尿を示した内の 1 例は外尿道口部での狭窄がみ られたが，他の症例では尿道狭窄はみられなかった。 腹圧性尿失禁症は16歳から55歳（33.7土16.1）で，こ の内の 2 例は夜尿症も示した。神経因性膀胼患者は 11 歳から72歳（44.9土19.7）で, 疾患の内訳はパーキン ソン氏病 2 例, オリーブ, 橋, 小脳萎縮症 2 例, 脳栓 塞 1 例, 流行性耳下腺炎後の横断性脊髄炎(第 4 胸髄)
Fig. 1 A coiled-tip balloon catheter.

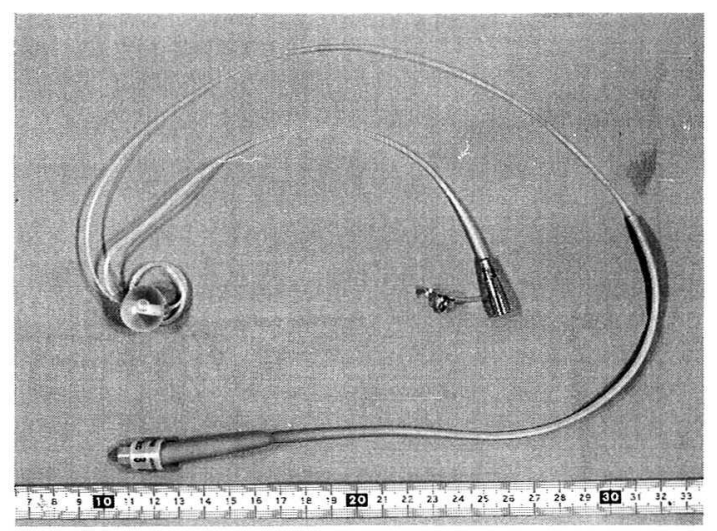

1 例，第11胸髄以下の外傷性脊髄損傷 1 例であった。

Fig. 1 に示す様な 4 Fr. の coiled-tip catheter とバ ルーンカテーテルを組み合わせたカテーテルと $4 \mathrm{Fr}$ の アトム栄養チューブが経尿道的に膀胱内に乗入され た。生理食塩水の注入は $4 \mathrm{Fr}$ のアトム栄養チューブか ら行い, 膀胱圧の測定は4Fr の coiled-tip catheter で 行った.腹圧は16Frのバルーンカテーテル (open-end) を肛門から挿入して測定した。圧測定の基準は恥骨上 縁とし，排尿筋圧は電気的に膀胱圧から腹圧を差し引 いて求められた。骨盤底筋群の筋電図測定は同芯針電 極（DISA 13L49）又は表面電極（DISA 13L20）を用 いて行った，検査は座位又は半座位で行い，膀脱圧， 腹腔圧，排尿筋圧，筋電図，尿流率の同時測定が最大 尿意時に $2 \sim 3$ 回行われた。次いで，排尿中断時の等 容性最大排尿筋収縮王（ $\mathrm{P}_{\text {iso }}$ と略す）の測定が行われ た。排尿中断はほぼ最大尿流を示した時点で行われ， 尿道外括約筋にて意識的に行ら方法と膀胼頝部でバ ルーンを膨らませて強制的に行う方法の 2 種類で行っ た。後者では尿流が中断されても排尿を持続するよう

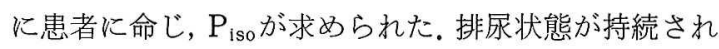
ているかどらかは骨盤底筋群の筋電図により判定され た。等容性排尿笳収縮での収縮スピードは我々が以前 に報告5)したように意識的及び強制的尿流中断の時の 最初の直線的に上昇する相の傾さから算出した。尿道 抵抗 (R) は排尿時同時測定から得られた最大尿流率 $\left(\mathrm{Q}_{\max }\right)$ と $\mathrm{P}_{\text {det }}, \max$ を用いて $\mathrm{R}=\frac{\mathrm{P}}{\mathrm{F}^{2}}$ の式から算出さ れた $\left(\mathrm{F}: \mathrm{Q}_{\max }, \mathrm{P}: \mathrm{P}_{\mathrm{det}}, \max \right)$.

圧測定，筋電図測定，尿流測定とその記録は DISA urodynamic equipmentを用いて行った。統計分析は 
$\mathrm{t}$ 検定を用いた。

$$
\text { 結 果 }
$$

意識的及び強制的な尿流中断による等容性最大排尿 筋収縮の再現性に関しては我々の報告5)及び他の報告 者 $^{233}$ により比較的充分な再現性がみられると考光ら れる.この為, 今回の検討では詳細には行っていない が, Fig. 2A，Bに示すように正常人においてそれぞれ 2 回の意識的及び強制的な尿流中断を行った所, 意識
的な方法による $\mathrm{P}_{\text {iso }}$ は 2 回共に $49 \mathrm{cmH}_{2} \mathrm{O}$ で，その収 縮スピードは $55.4 \mathrm{cmH}_{2} \mathrm{O} / \mathrm{sec}$ と $48.4 \mathrm{cmH}_{2} \mathrm{O} / \mathrm{sec} て ゙$ あった。強制的な方法による $\mathrm{P}_{\mathrm{iso}}$ は 2 回共に $43 \mathrm{cmH}_{2} \mathrm{O}$

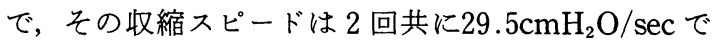
あった。このよらにそれぞれ 2 回ずつの検討であるが， 同じ値か又は似た值が得られた。

意識的尿流中断による等容性排尿筋収縮曲線は典型 的には直後の直線的に上昇する部分とそれに続く上に

Fig. 2 Maximum isometric detrusor pressures $\left(\mathrm{P}_{\text {iso }}\right)$. A, curves obtained by stopping urinary flow with external urethral sphincter voluntarily in 30year-old volunteer. Flow was stopped 2times. B, curves obtained by stopping urinary flow with balloon catheter at the bladder neck forcibly in 59-year-old volunteer. Latter halves of voidings are abbreviated. A part of curve 2 has artifact.

(A)

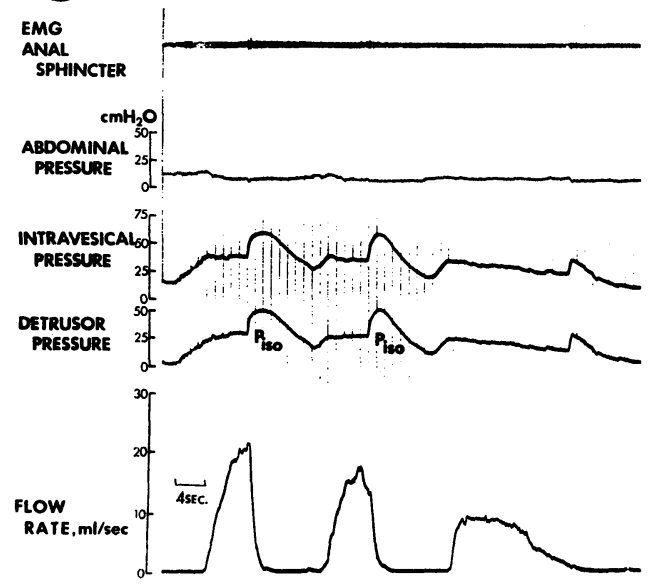

(B)

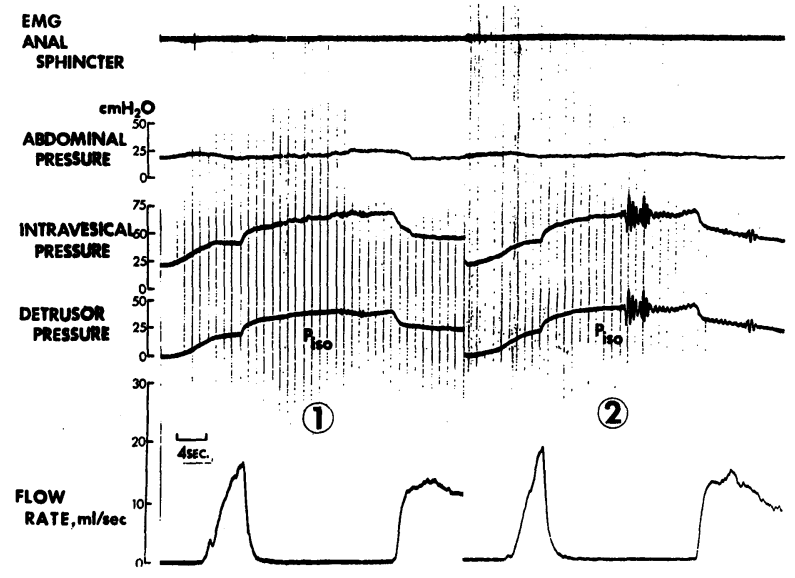

Table 1 Mean and standard deviations of parameters of pressure-flowelectromyographic studies in volunteers and patients with enuresis and stress incontinence.

\begin{tabular}{|c|c|c|c|}
\hline & $\begin{array}{l}\text { Volunteers } \\
\text { (7 pts.) }\end{array}$ & $\begin{array}{l}\text { Enuresis } \\
\text { (13 pts.) }\end{array}$ & $\begin{array}{l}\text { Stress } \\
\text { incontinence } \\
\text { ( } 3 \text { pts.) }\end{array}$ \\
\hline $\begin{array}{l}\text { Maximum detrusor } \\
\text { pressure }\left(\mathrm{cmH}_{2} \mathrm{O}\right)\end{array}$ & $24.5 \pm 5.6^{*, * *}$ & $42.7 \pm 9.3^{*}$ & $26.3 \pm 10.5$ \\
\hline \multicolumn{4}{|l|}{$\begin{array}{l}\text { Maximum isometric } \\
\text { detrusor pressure } \\
\left(\mathrm{cmH} \mathrm{H}_{2} \mathrm{O}\right) \text { : }\end{array}$} \\
\hline $\begin{array}{l}\text { Voluntary flow-stop } \\
\text { technique }\end{array}$ & $34.9 \pm 11.3^{*, * *}$ & $\begin{array}{l}85.5 \pm 30.4^{*, * *} \\
\quad(11 \text { pts. })\end{array}$ & $\begin{array}{l}31 \\
(1 \text { pts. })\end{array}$ \\
\hline $\begin{array}{l}\text { Forced flow-stop } \\
\text { technique }\end{array}$ & $43.3 \pm 14.5^{* * * *}$ & $118 \pm 32.9^{* * *}$ & $44.4 \pm 10.9$ \\
\hline \multicolumn{4}{|l|}{$\begin{array}{l}\text { First slope of curve } \\
\text { obtained with : }\end{array}$} \\
\hline $\begin{array}{l}\text { Voluntary flow-stop } \\
\text { technique }\left(\mathrm{cmH}_{2} \mathrm{O} / \mathrm{sec} \text {. }\right)\end{array}$ & $22.8 \pm 16.6^{*}$ & $\begin{array}{c}78.5 \pm 44.2^{*} \\
(11 \text { pts. })\end{array}$ & $\begin{array}{l}16.8 \\
(1 \text { pts.) }\end{array}$ \\
\hline $\begin{array}{l}\text { Forced flow-stop } \\
\text { technique }\left(\mathrm{cmH}_{2} \mathrm{O} / \mathrm{sec} \text {. }\right)\end{array}$ & $20.5 \pm 10.8^{*}$ & $\begin{array}{c}61.4 \pm 26.5^{*} \\
(11 \text { pts. })\end{array}$ & $12.9 \pm 2.7$ \\
\hline
\end{tabular}


凸となった抑制がかかった部分の 2 つの相に分けるこ とができる(Fig. 2A，3A)．強制的尿流中断による等 容性排尿笳収縮曲線は典型的には直後の直線的に上昇 する部分とそれに続く緩徐に上昇する部分，そしてほ
ぼ平坦となった部分の 3 つの相に分けることができる (Fig. 2B, 3B).我々はこれらの 2 つ尿流中断方法で 得られる曲線の最初の直線的に上昇する部分を排尿筋 収縮スピードをあらわすものとみなした。

Fig. 3 Maximum isometric detrusor pressures $\left(\mathrm{P}_{\text {iso }}\right)$ in 12-year-old girl with enuresis. A, 2 phases of $P_{\text {iso }}$ curve obtained with voluntary flow-stop technique. $\mathrm{B}, 3$ Phases of $\mathrm{P}_{\text {iso }}$ curve obtained with forced flow-stop technique.

(A)

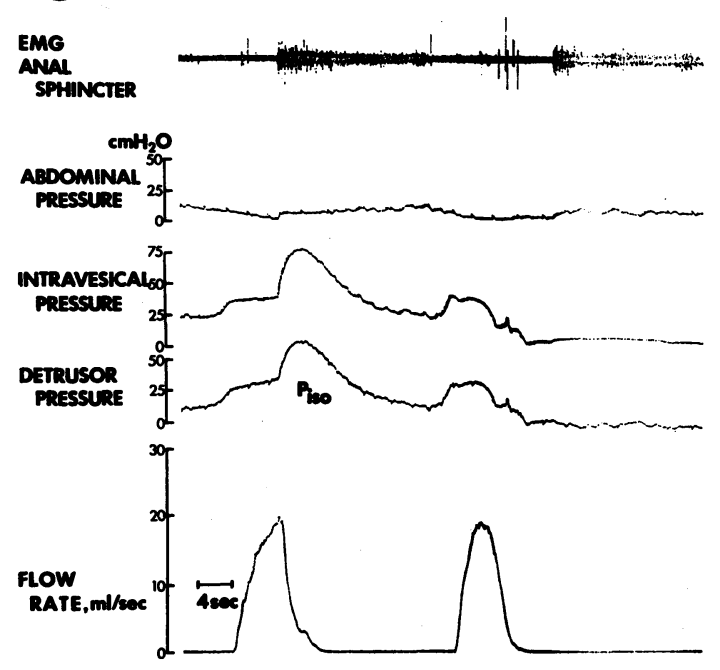

(B)

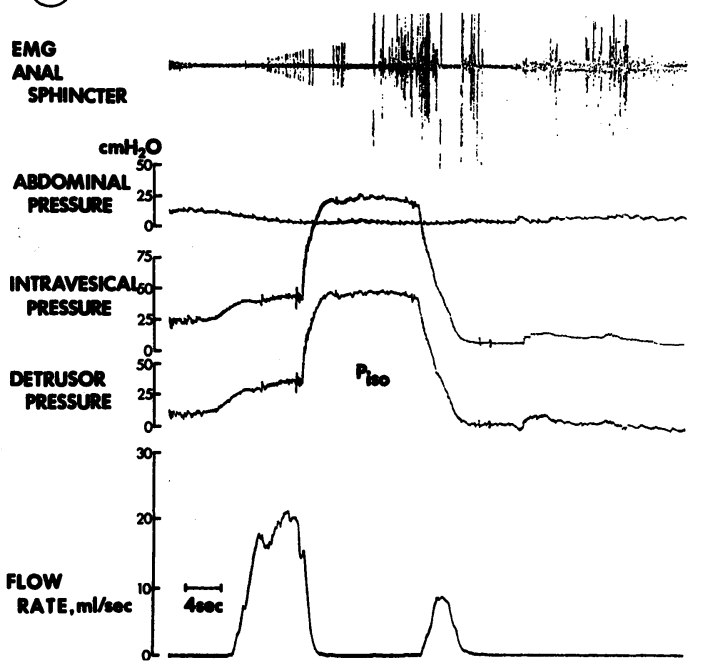

Fig. 4 Correlation between maximum isometric detrusor pressure $\left(\mathrm{P}_{\text {iso }}\right)$ and speed of detrusor contraction $\left(\mathrm{SP}_{1 \mathrm{so}}\right)$. $\mathrm{A}$, voluntary ( $\mathrm{v}$ ) flow-stop technique. $\mathrm{y}=0.601 \mathrm{x}+30.5, \mathrm{r}=0.78$. B, forced ( $\mathrm{f}$ ) flow-stop technique. $\mathrm{y}=0.83 \mathrm{x}+51.1, \mathrm{r}=$ 0.62 . $\Delta$, volunteer. $\triangle$, enuresis. $\bullet$, stress incontinence. $\bigcirc$, neurogenic bladder dysfunction.

(A)

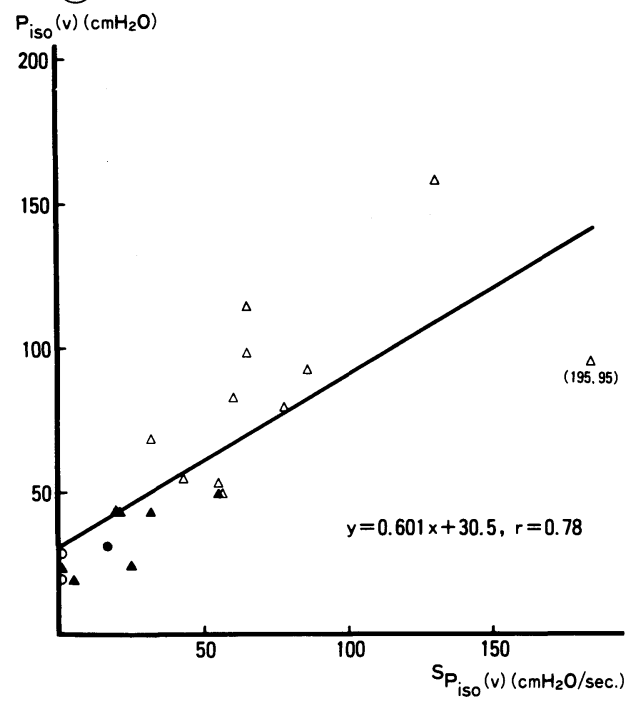

(B)

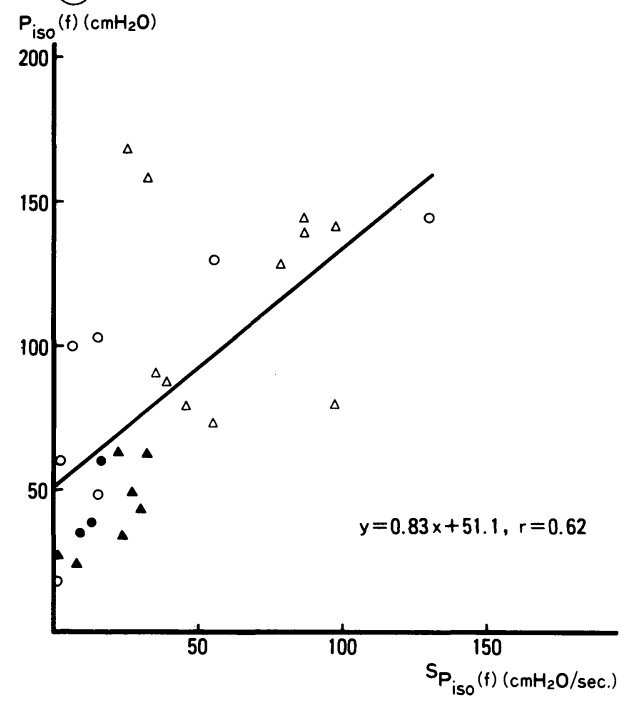


Table 1 亿正常人, 遺尿症, 腹圧性尿失禁患者での 排尿時最大排尿筋圧 $\left(\mathrm{P}_{\mathrm{det}}, \max \right)$, 意識的及び強制的 尿流中断によって得られた $\mathrm{P}_{\text {iso }}$ とその収縮スピードを 示している. $P_{\text {iso }}$ と収縮スピードは Fig. 4A，B に示す ように意識的及び強制的尿流中断のそれぞれで比較的 いい相関関係がみられた（ $\mathrm{r}=0.78 ， 0.62 ）$.

尿道抵抗 $(\mathrm{R})$ と意識的及び強制的尿流中断によって 得られた $\mathrm{P}_{\text {iso }}$ との相関を求めた(Fig. $\left.5 \mathrm{~A}, \mathrm{~B}\right)$. これで は相関係数はそれぞれ $\mathrm{r}=0.30,0.28$ と余りいい相関 はみられなかった。

正常女性：意識的及び強制的尿流中断による $\mathrm{P}_{\mathrm{iso}}$ は $\mathrm{P}_{\text {det }}, \max よ り$ 統計学的に有意に高值を示した $(\mathrm{p}<$ $0.05,0.01)$. そして, 意識的及び強制的尿流中断によっ て得られたそれぞれの $\mathrm{P}_{\text {iso }}$ 間では統計学的に有意に強 制的方法によるものの方が高值を示した $(\mathrm{p}<0.05)$ が

Fig. 5 Correlation between urethral resistance (R) and maximum isometric pressure $\left(\mathrm{P}_{\text {iso }}\right)$. A, voluntary (v) flow-stop technique. $\mathrm{y}=93.0 \mathrm{x} \pm$ $48.5, r=0.30 . B$, forced (f) flow-stop technique. $\mathrm{y}=102 \mathrm{x} \pm 67.1, \mathrm{r}=0.28$.

(A)

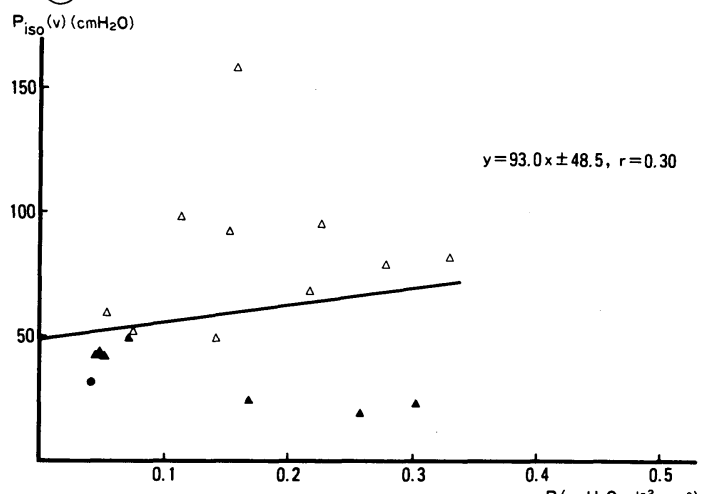

(B)

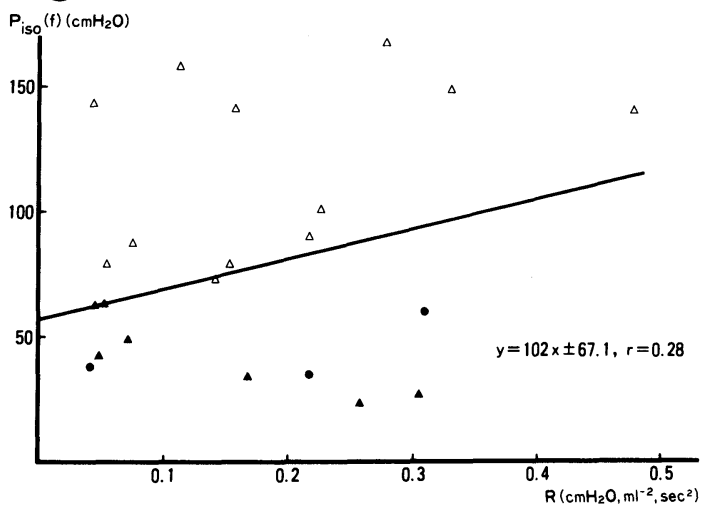

2つの方法によるそれぞれの排尿筋収縮スピードには 統計学的な有意差はみられなかった。

遺尿症：意識的及び強制的尿流中断による $\mathrm{P}_{\text {iso }}$ は $\mathrm{P}_{\mathrm{det}}, \max$ より統計学的に有意に高值を示した（p< 0.01). そして, 意識的及び強制的尿流中断によって得

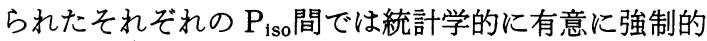
方法によるものの方が高値を示した $(\mathrm{p}<0.05)$ が, 2 つの方法によるそれぞれの排尿筋収縮スピードには有 意差はみられなかった。遺尿症群と正常人との間には $\mathrm{P}_{\text {det }}, \max$, 意識的及び強制的方法による $\mathrm{P}_{\mathrm{iso}}$ 及び排尿 筋収縮スピードについて統計学的な有意差がみられた $(\mathrm{p}<0.01)$. Fig. 3A，B に同一患者での 2 つの尿流中 断方法による等容性排尿筋収縮曲線を示す。意識的尿 流中断による $\mathrm{P}_{\text {iso }}$ とその収縮スピードはそれぞれ54 $\mathrm{cmH}_{2} \mathrm{O}$ と $42.9 \mathrm{cmH}_{2} \mathrm{O} / \mathrm{sec}$ であり, 強制的尿流中断に

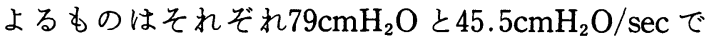
あった。筋電図には一部アーティファクトがみられる。 外尿道口狭窄を示した女児では $\mathrm{P}_{\text {det }}, \max$ は $52 \mathrm{cmH}_{2}$ $\mathrm{O}$ とやや高値を示し, 術後は $38 \mathrm{cmH}_{2} \mathrm{O}$ と低下した. 13 例の患者の内，意識的尿流中断ができなかった症例は 2 例あり，又，強制的尿流中断が技術的にうまくでき なかった症例は 2 例あった。

腹圧性尿失禁：検討を行った症例は 3 例で，この内 の 2 例には夜尿症もみられた。意識的尿流中断がうま くできた症例は 1 例で， 2 例では全くできないか，不 充分にしかできなかった，症例が少ない為，統計学的

Fig. 6 Maximum isometric detrusor pressures $\left(P_{1 s o}\right)$ in 55-year-old female with stress incontinence. Flow was stopped 2times.

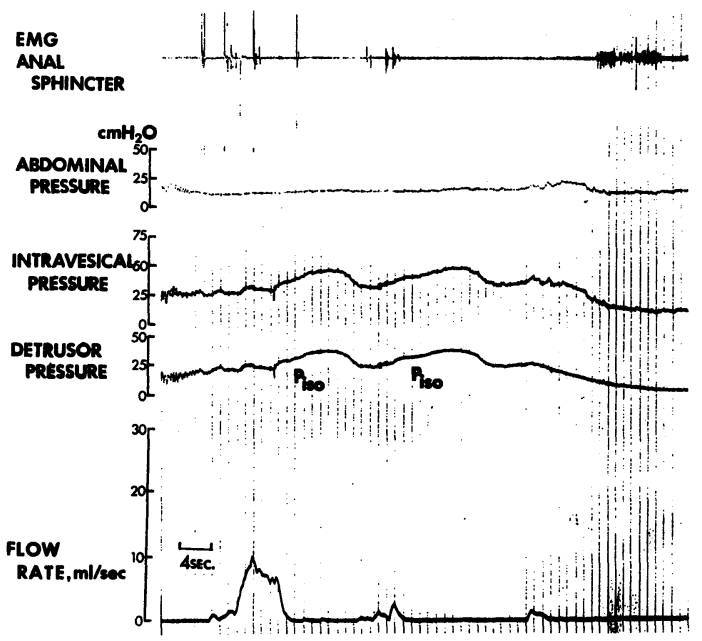


Table 2 Patients with neurogenic bladder dysfunction.

\begin{tabular}{|c|c|c|c|c|c|c|c|}
\hline \multirow{2}{*}{$\begin{array}{l}\text { Pt. } \\
\text { No. }\end{array}$} & \multirow{2}{*}{ Age } & \multirow{2}{*}{ Diagnosis } & \multirow{2}{*}{$\begin{array}{l}\text { Maximum } \\
\text { Detrusor } \\
\text { Pressure } \\
\left(\mathrm{cmH}_{2} \mathrm{O}\right)\end{array}$} & \multicolumn{2}{|c|}{$\begin{array}{l}\text { Maximum Isometric } \\
\text { Pressure }\left(\mathrm{cmH}_{2} \mathrm{O}\right)\end{array}$} & \multicolumn{2}{|c|}{$\begin{array}{l}\text { Pressure Increase } \\
\left(\mathrm{cmH}_{2} \mathrm{O} / \mathrm{sec} .\right)\end{array}$} \\
\hline & & & & $\begin{array}{l}\text { Voluntary } \\
\text { Technique }\end{array}$ & $\begin{array}{l}\text { Forced } \\
\text { Technique }\end{array}$ & $\begin{array}{l}\text { Voluntary } \\
\text { Technique }\end{array}$ & $\begin{array}{l}\text { Forced } \\
\text { Technique }\end{array}$ \\
\hline 1 & 36 & O.P.C.A. & 20 & - & 48 & - & 15.3 \\
\hline 2 & 52 & O.P. C. A. & 20 & 20 & 100 & 0 & 5.5 \\
\hline 3 & 53 & Parkinsonism & 18 & - & 18 & - & 0 \\
\hline 4 & 63 & Parkinsonism & 30 & 30 & 60 & 0 & 2.1 \\
\hline 5 & 72 & Cerebral infarction & 27 & - & 130 & - & 55.3 \\
\hline 6 & 11 & $\begin{array}{r}\text { Postmumps myelitis } \\
\left(\mathrm{Th}_{4}\right)\end{array}$ & 34 & - & 144 & - & 129 \\
\hline 7 & 27 & $\begin{array}{l}\text { Th"1 incomplete } \\
\text { spinal injury }\end{array}$ & 54 & - & 103 & - & 15.3 \\
\hline
\end{tabular}

O. P. C. A. : olivo-ponto-cerebellar atrophy

な検討は行っていない. Fig. 6 亿強制的尿流中断によ る 2 回の等容性排尿筋収縮曲線を示している。 $\mathrm{P}_{\mathrm{iso}}$ は

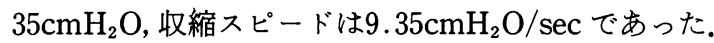
この症例では意識的尿流中断はできなかった。

神経因性膀脱：Table 2 に個々の患者と得られた データを示す．5例の患者では意識的尿流中断ができ なかった. Fig. 7A，Bに脳栓塞患者での強制的尿流中 断による等容性排尿筋収縮曲線を示す．Fig. 7A では $\mathrm{P}_{\text {iso }}$ が 2 段になってみられるが，1 段目の $\mathrm{P}_{\text {iso }}$ は途中 からバルーンカテーテル周囲からの尿漏れがあり， 2 段目の $\mathrm{P}_{\mathrm{iso}}$ は尿漏れを完全に止めた後に得られたもの で $\mathrm{P}_{\mathrm{iso}}$ 及び収縮スピードはこちらのデーターを採用し た． $\mathrm{P}_{\text {Iso }}$ の傾きは腹圧にアーティファクトがみられる 為, 膀胼圧の方で求めている.Fig. 7B はプロバンサイ ンを内服中の等容性排尿筋収縮曲線であるが， $\mathrm{P}_{\text {iso }}$ は

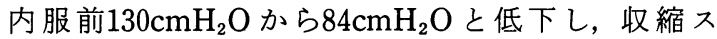
ピードは内服前 $55.3 \mathrm{cmH}_{2} \mathrm{O} / \mathrm{sec}$ から $19.7 \mathrm{cmH}_{2} \mathrm{O} / \mathrm{sec}$ と低下した。な拈， $\mathrm{P}_{\mathrm{det}}, \max$ は内服前 $27 \mathrm{cmH}_{2} \mathrm{O}$, 内 服後 $24 \mathrm{cmH}_{2} \mathrm{O}$ であった。

\section{考 察}

我々は今回, 女性での $\mathrm{P}_{\text {iso }}$ の測定について報告した。 $\mathrm{P}_{\text {iso }}$ の測定の報告は少なく, 従って男女比較もほとん どなされていない. 現在迄の報告として, Susset ら4)は 正常男子 4 例で $43.75 \pm 13.84 \mathrm{mmHg}$, 正常女性 3 例で $25 \pm 10.4 \mathrm{mmHg}$ と報告し, 又, Griffiths ${ }^{2)}$ は正常男女は $50 \sim 100 \mathrm{cmH}_{2} \mathrm{O}$ としている。これらはいずれも意識的 尿流中断による $\mathrm{P}_{\mathrm{Iso}}$ の值である.我々は今回, 以前に報 告した ${ }^{5}$ 正常男性 7 例に新しく8 例を加えて15例 （20～62歳，42.4 $413.0 ）$ とし，今回の正常女性 7 例と $\mathrm{P}_{\mathrm{det}}, \max , \mathrm{P}_{\mathrm{iso}}$ 及び排尿筋収縮スピードを比較した (Table 3).この結果, $\mathrm{P}_{\mathrm{det}}, \max$ と意識的方法による
Fig. 7 Maximum isometric detrusor pressures $\left(\mathrm{P}_{\text {iso }}\right)$. A, curves obtained with forced stop-flow technique in 72-year old female with cerebral infarction. B, using Propantheline bromide.
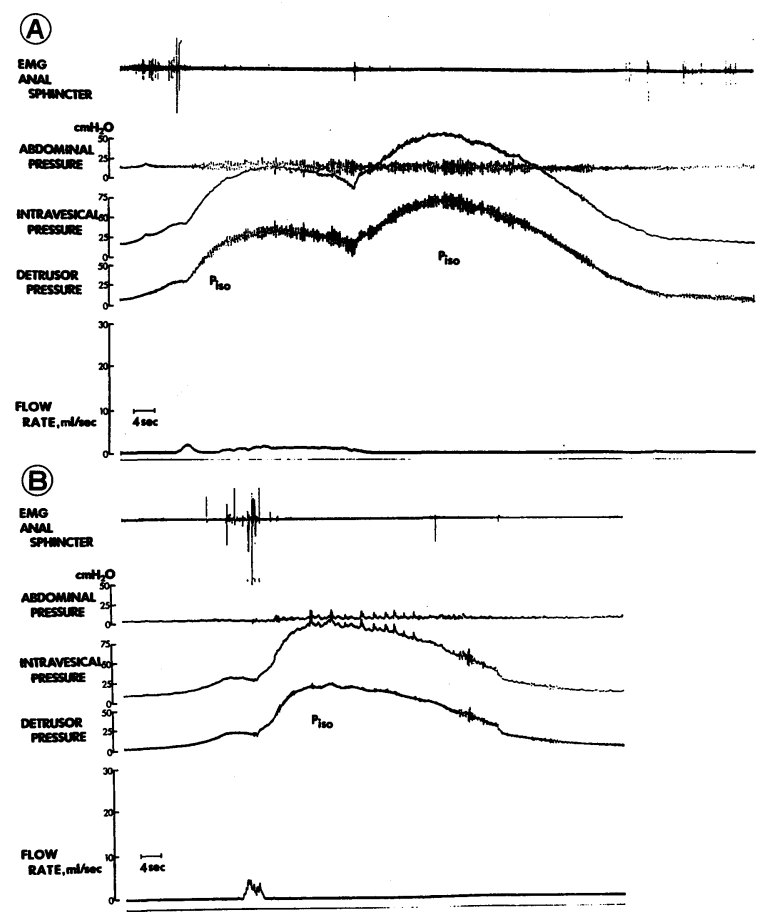

$\mathrm{P}_{\text {iso }}$ に $\mathrm{p}<0.01 て ゙$, 強制的方法による $\mathrm{P}_{\mathrm{iso}}$ と意識的方法 による収縮スピードに $\mathrm{p}<0.05 て ゙$ 統計学的な有意差が みられた。 $P_{\text {det }}, \max$ は統計学的に女性が男性より低 值であることは尿道抵抗から考えて当然であると思わ れる，等容性排尿筋収縮圧に関して性差がみられたこ とについては，一部は男女での尿道抵抗の差から説明 できるかむ知れない，我々の検討に打いては尿道抵抗 
Table 3 Mean and standard deviations of parameters of pressure-flowelectromyographic studies in female and male volunteers.

\begin{tabular}{|c|c|c|}
\hline & \multicolumn{2}{|c|}{ Volunteers } \\
\hline & $\begin{array}{l}\text { Female } \\
\text { ( } 7 \text { pts.) }\end{array}$ & $\begin{array}{c}\text { Male } \\
(15 \text { pts. })\end{array}$ \\
\hline $\begin{array}{l}\text { Maximum detrusor pressure } \\
\left(\mathrm{cmH}_{2} \mathrm{O}\right)\end{array}$ & $24.5 \pm 5.6^{*}$ & $38.0 \pm 11.3^{*}$ \\
\hline \multicolumn{3}{|l|}{$\begin{array}{l}\text { Maximum isometric detrusor } \\
\text { pressure }\left(\mathrm{cmH}_{2} \mathrm{O}\right) \text { : }\end{array}$} \\
\hline $\begin{array}{l}\text { Voluntary flow-stop } \\
\text { technique }\end{array}$ & $34.9 \pm 11.3^{*}$ & $54.1 \pm 17.9^{*}$ \\
\hline $\begin{array}{l}\text { Forced flow-stop } \\
\text { technique }\end{array}$ & $43.3 \pm 14.5^{* *}$ & $63.8 \pm 27.3^{* *}$ \\
\hline \multicolumn{3}{|l|}{$\begin{array}{l}\text { First slope of curve } \\
\text { obtained with: }\end{array}$} \\
\hline $\begin{array}{l}\text { Voluntary flow-stop } \\
\text { technique }\left(\mathrm{cmH}_{2} \mathrm{O} / \mathrm{sec} \text {. }\right)\end{array}$ & $22.8 \pm 16.6^{* *}$ & $45.2 \pm 31.9^{* *}$ \\
\hline $\begin{array}{l}\text { Forced flow-stop } \\
\text { technique }\left(\mathrm{cmH}_{2} \mathrm{O} / \mathrm{sec} .\right)\end{array}$ & $20.5 \pm 10.8$ & $34.4 \pm 24.1$ \\
\hline
\end{tabular}

$* p<0.01, * * p<0.05$

と $\mathrm{P}_{\mathrm{iso}}$ は余りいい相関がみられなかったが, Susset $ら^{3)}$ は尿道抵抗と $\mathrm{P}_{\text {iso }}$ とは比較的いい相関がみられた と報告している。そして, 我々の以前の報告 ${ }^{5}$ では下部 尿路閉塞が存在すれば $\mathrm{P}_{\text {iso }}$ は増大がみられた。これら のことから $\mathrm{P}_{\mathrm{iso}}$ の性差は尿道抵抗が関与している可能 性が考えられる．排尿筇収縮スピードは $\mathrm{P}_{\text {iso }}$ との相関 がみられる為, 排尿筇収縮スピードの性差も $\mathrm{P}_{\text {iso }}$ の性 差と同じょうに考えることができるかも知れない。強 制的尿流中断での収縮スピードに有意差がみられな かったのは尿流中断の方法が女性では膀胱䅡部で行う のに対して, 男性では陰茎部尿道での圧迫で行うとい ら方法に差がある為かも知れない。

$\mathrm{P}_{\text {det }}, \max$ と $\mathrm{P}_{\text {iso } 0}$ の間には正常人, 遺尿症の群でそれ ぞれ統計学的な有意差がみられた。我々は以前, 男性 で報告した ${ }^{5)}$ ように正常人, 下部尿路閉塞, 遺尿症の各 群で同様な有意差を認めた。これは尿道抵抗を最大に することにより排尿時の排尿筋収縮圧とは異なった， 通常, これより高值を示す潜在的な排尿筋収縮力を測 定していることによるものだと考号れる．意識的及 び強制的尿流中断によって得られる等容性排尿笳収縮 曲線は女性に打いても男性之同様に典型的にはそれぞ れ 2 相と 3 相に分けることができる。それぞれの最初 の相はほぼ直線に近く，排尿筋収縮スピードを示すと 考えられる. 意識的方法によって得られる等容性排尿 筋収縮曲線の第 2 相は上に凸で, 排尿筋収縮に対して 抑制がかかった部分だと考えられ，そして強制的方法 による $\mathrm{P}_{\mathrm{iso}}$ が意識的方法によるものより統計学的に有 意に高値を示したことは $2 つ の$ 尿流中断方法が排尿筋
収縮に対して，それぞれ促進と抑制をあらわすことを 裏付けたものだと考えられる。

正常人と遺尿症との間には $\mathrm{P}_{\mathrm{det}}, \max , 2$ つの尿流 中断方法により得られた $\mathrm{P}_{\text {iso }}$ 及び排尿筇収縮スピード にそれぞれ統計学的な有意差がみられた。この場合， まず 2 群間での年齢差が問題になると考兄られる. Griffiths ${ }^{2}$ は年齢と $\mathrm{P}_{\text {iso }}$ は関係がみられないとしてい るが，これには20歳以下の症例はほとんど含まれてい ない為, 今回の我々の場合のように 20 歳以下の症例が 多い場合は年齢と $\mathrm{P}_{\mathrm{Iso}}$ の関係は不明である.この為, こ の 2 群間での単純な比較は問題があると考えられる が，遺尿症群で 20 歳以上の症例についてみた場合，43 歳と66歳の症例で意識的方法による $\mathrm{P}_{\text {Iso }}$ はそれぞれ $98,79 \mathrm{cmH}_{2} \mathrm{O}$, 強制的方法による $\mathrm{P}_{\mathrm{iso}}$ はそれぞれ 158 , $168 \mathrm{cmH}_{2} \mathrm{O}$ と高值を示した. このことから 2 群間に年 齢の差が存在しても, これらの群の比較はある程度の 意味があるものだと考えられる. Griffiths ${ }^{2}$ は女性では 遺尿症や腹圧性尿失禁を示す患者は正常人より $\mathrm{P}_{\mathrm{iso}}$ が 低値を示すようであるとしている，今回の我々の検討 では 2 つの尿流中断方法により得られた $\mathrm{P}_{\mathrm{Iso}}$ は遺尿症 に扣いては正常人より有意に高値を示し, 腹圧性尿失 禁患者では症例が少ない為, 統計学的な検討は行って いないが，正常人と似た値と考えられた。このように Griffiths の報告2) と異なる結果が得られたのは，1つ は遺尿症群の年齢が我々の症例の方がかなり若いとい らことと,もら1つは尿流中断方法が Griffiths の報 告2) と比べて我々の方は尿流中断時間が長いといら方 法の違いからかも知れない，遺尿症群に㧊いては不安 
定膀胱を示す症例が多くみられた。不安定膀胱の場合， 不随意の排尿筋収縮に対して尿道外括約筋の意識的な 収縮が生じ，これにより排尿筋の肥大を生じる可能性 がある，以前の男性に乱ける我々の報告5では排尿筋 の代償性肥大が生じていると考兄られる前立腺肥大 症，尿道狭窄症といった下部尿路閉塞群では正常人と 比べて $\mathrm{P}_{\mathrm{iso}}$ の值は高值を示した. 又, 男性での遺尿症で も正常人と比べて $\mathrm{P}_{\mathrm{iso}}$ の值は高值を示した. 我々の今 回の検討の結果から考兵ると, 遺尿症に招いては排尿 筋に対して中枢及び末梢レベルでの促進状態が存在 し，これが $\mathrm{P}_{\mathrm{iso}}$ の高值につながるものだと考えられる。 $\mathrm{P}_{\text {iso }}$ と排尿筋収縮スピードに関しては, 今回の女性 での検討でも以前の男性での検討5) と同様に比較的い い相関関係が得られた. Susset ら゙は男性と女性を含 む症例で同様な相関関係を報告している。しかし, Griffiths ${ }^{21}$ は男女共に余りいい相関は報告して扔らず, 逆に下部尿路閉塞症例に打いては収縮スピードの低下 が多くみられるとしている。これらの結果の違いは排 尿筋収縮スピードの求め方に起因しているものだと考 えられる，尿流中断により得られる等容性排尿筋収縮 曲線から排尿筋収縮スピードを求めた場合には, 男女 共に $\mathrm{P}_{\text {iso }}$ と収縮スピードには相関関係が存在している ようである。

排尿中断による $\mathrm{P}_{\mathrm{Iso}}$ の測定は現在，それ程普及した 検查とは言えないが，予備力を含めた排尿筋収縮の質 を判定する 1 つのパラメーターとなりらると考えられ る. 今後, 正常人を含め, 種々の疾患に扔いて検討が 必要だと思われる。

\section{結 語}

意識的及び強制的尿流中断により等容性排尿筋収縮
を検討した。等容性排尿筋収縮曲線は男性と同様に, 典型的には意識的方法によるものは 2 相に, 強制的方 法によるものは 3 相に分けることができた。

これらの $2 つ の$ 方法で得られた等容性排尿筋圧は排 尿時最大排尿筋圧より有意に高值を示した，又，強制 的方法により得られた等容性排尿筋圧は意識的方法に より得られたものと比べて, 正常女性, 遺尿症群で有 意に高值を示したが，排尿筋収縮スピードにはこれら の 2 つの方法による有意差はみられなかった．等容性 排尿筋收縮圧と排尿筋収縮スピードには男性の場合と 同様に比較的いい相関関係がみられた。

\section{文献}

1) Bates, P., Bradley, W.E., Glen, E., Griffiths, D., Melchior, H., Rowan, D., Sterling, A., Zinner, M. and Hald, T.: The standardization of terminology of lower urinary tract function. J. Urol., 121, 551-554, 1979.

2) Griffiths, D.J.: Urodynamic assessment of bladder function. Brit. J. Urol., 49, 29-36, 1977.

3) Susset, J.G., Brissot, R.B. and Regnier, C.H.: The stop-flow technique: A way to measure detrusor strength. J. Urol., 127, 489-494, 1982.

4) Coolsaet, B.L.R.A.: Cystometry. In: Clinical Gynecologic Urology. Edited by S.L. Stanton, 1st ed., p. 59-81, The C.V. Mosby Co., St. Louis, 1984.

5) Morita, M., Okamoto, M., Ochi, K. and Takeuchi, M.: Isometric detrusor pressure in the male patient : A comparison between voluntary urethral sphincter contraction and forced penile compression techniques. J. Urol., 134, 1161 $-1165,1985$.

（1986年 7 月21日受付） 